\title{
TEOLOGICZNE PODSTAWY MONASTYCZNEJ MISTYKI NESTORIAŃSKIEJ (SYRO-ORIENTALNEJ) W LISTACH JANA Z DALIJATA
}

W jednym z Listów Jan z Dalijata tak opisuje swoje doświadczenie mistyczne i trudności w ludzkim poznawaniu Bożych tajemnic:

„Pióro spala się (مn) w sile Twego ognia, o Jezu, i moja prawa dłoń wstrzymała się w pisaniu. Moje oczy płoną († ( piękna. [...] Mój duch zachwycił się cudownością, którą sprawiłeś, i dlatego uważam siebie jakbym nie istniał. Płomień zapłonął w moich kościach i źródła trysnęly wodą na moje ciało, aby nie zostało pochłonięte. O, piecu oczyszczający, w którym Rzemieślnik oczyścił swoje stworzenie! O, szato światła, którą nasza wola zdarła z nas, a którą teraz jesteśmy na nowo odziani w ogniu! Pozwól mi, mój Panie, dać to, co święte Twoim dzieciom. Nie daję tego psom, ale tym, którzy kochają Ciebie, daję perły (Rhel is), które

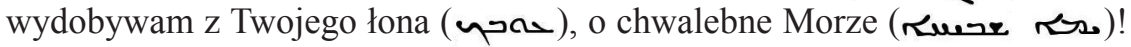
I nie rzucam ich między świnie, aby ich nie podeptały nogami (por. Mt 7, 6)"”.

Autor próbuje opisać stan wewnętrznego zjednoczenia z Bogiem. W jego relacji intensywność mistycznego doświadczenia obejmuje całego człowieka, zarówno jego ciało, jak zmysły i inteligencję (duch). Eksponowane reakcje cielesne przenikają się z duchowymi, tworząc jedną uporządkowaną kompozycję. W jej fizyczno-psychicznej strukturze spotykają się elementy wydawać by się mogło wykluczające się, gdy mistyk uświadamia sobie bezradność ludzkiego przekazu Bożych tajemnic. Autor sugestywnie przekonuje, że w konfrontacji z rzeczywistością transcendentną pozostaje jedynie przerwać

${ }^{*}$ Ks. dr hab. Andrzej Uciecha, prof. UŚ - profesor nadzwyczajny w Katedrze Teologii Patrystycznej i Historii Kościoła na Wydziale Teologicznym Uniwersytetu Śląskiego w Katowicach; e-mail: andrzej.uciecha@wp.pl.

${ }^{1}$ Joannes de Dalyatha, Epistula 4, 6, ed. M. Hansbury: The Letters of John of Dalyatha, Texts from Christian Late Antiquity 2, Piscataway 2006, 27, tłum. własne. W opracowaniu wykorzystano to wydanie krytyczne. Należy wspomnieć wcześniejsze opracowanie źródłowe - ed. R. Beulay: La Collection des Lettres de Jean de Dalyatha, PO 39, fasc. 3 (180), Turnhout 1978. 
relację. Ma on całkowitą świadomość swojej poznawczej ograniczoności ${ }^{2}$, a mimo to dalej prowadzi swój ułomny przekaz. Dyskurs mistyka na temat wewnętrznych przeżyć staje się istotnym elementem samego mistycznego fenomenu. Determinacja w kontynuacji opisu wbrew ludzkiej logice wynika z poczucia obowiązku trwania w nieustannej adoracji $\mathrm{Boga}^{3}$ i naśladowania Mistrza. Co więcej, poziom świadomości tej chrystologicznej imitacji wzrasta wraz z pragnieniem oczyszczającej przemiany (w wodzie i ogniu). Mistyk im intensywniej doświadcza swojej ułomności, tym wyższy osiaga stan oczyszczenia i tym bardziej czuje się przynaglony do udziału w niekończącej się aktualizacji dzieła „Rzemieślnika”. Ta soteriologiczna bosko-ludzka komunikacja wymaga jednak zachowania roztropności, zgodnie z ewangeliczną przestroga, aby cennych pereł nie rzucać przed świnie. Okazuje się, że prezentowana teologia mistyki nie jest zawieszona w chmurach nieosiagalnych idei, ale „chodzi po ziemi”. Należy zauważyć, że w swoim mistycznym przekazie Autor wykorzystuje obraz perły ( porównaniem stosowanym w dziełach wczesnosyryjskich ojców, Afrahata Persa $^{4}$ i Efrema Syryjczyka ${ }^{5}$. W naszym przedłożeniu pragniemy przybliżyć mało znane w kręgu polskiej patrologii postać i dzieło nestoriańskiego autora cytowanego fragmentu. Zarys kontekstu historyczno-teologicznego ułatwi zrozumienie treściowej zawartości jego mistycznego nauczania, z którego pragniemy przeanalizować interesujące wątki, ukryte w wyrażeniach ,pamięć

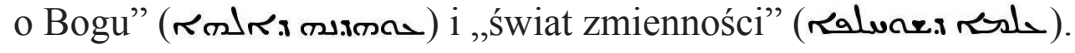

1. Autor i jego dzielo. Autorem zacytowanej modlitwy uwielbienia jest Jan z Dalijata, znany także pod imionami Jan Saba lub Starzec ${ }^{6}$. Ten nesto-

\footnotetext{
${ }^{2}$ Por. tenże, Epistula 41, ed. Hansbury, s. 188-189: ,Now you see my foolishness!"(

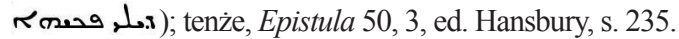

${ }^{3}$ Por. tenże, Epistula 50, 2, ed. Hansbury, s. 233.

${ }^{4}$ Por. Aphraates, Demonstratio 22, 26, ed. J. Parisot: Aphraatis Sapientis Persae Demonstrationes, PSyr 1, Paris 1894, 1980², 1045, 26 - 1048, 7, tłum. własne: „Jeśli więc zapyta o te kwestie, które są zbyt trudne dla niego, [wtedy] mądrzy tłumacze, którzy badają naukę, gdy będzie ich dziesięciu, opowiedzą mu o dziesięciu twarzach/obliczach jednego słowa, i otrzyma to, co jest w stanie [przyjąć], aby z powodu tego, czego nie jest w stanie [przyjąćc, nie kpił sobie z mędrców. Słowo

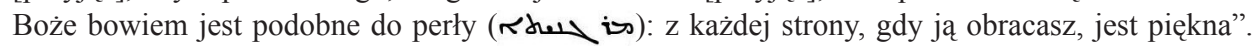
Zob. A. Uciecha, Egzegeza biblijna w komentarzach syryjskich Afrahata, Efrema, Iszdoada z Merw i Teodora Bar Koni. Zarys problematyki, VoxP 37 (2017) t. 67, 675-676.

${ }^{5}$ Por. Ephraem Syrus, Hymnus de fide 81 (De Margarita I), 1, ed. E. Beck, CSCO 154, Scriptores Syri 73, Louvain 1955, 248, tłum. własne: „Pewnego dnia, moi bracia, wziąłem perłę. I spostrzegłem w niej, synowie królestwa, symbole, obrazy i typy tego Majestatu. I stała się źródłem. I ugasiłem pragnienie tajemnicami Syna. Refren: Błogosławiony jest ten, który porównał królestwo Najwyższego do perły. I położyłem ją, moi bracia, na mojej dłoni, aby lepiej ją zbadać. I zabrałem się do przyglądania się jej z jednej strony. Ale ona miała swoje oblicze na każdej stronie. Podobnie obserwujemy Syna, Tego, którego [tajemnicy] nie można zgłębić, ponieważ On jest całkowitym światłem”. Zob. Uciecha, Egzegeza biblijna w komentarzach syryjskich Afrahata, s. 677.

${ }^{6}$ Por. B. Colless, Yohannan of Dalyatha ( $8^{\text {th }}$ centur.), w: The Gorgias Encyclopedic Dictionary
} 
riański mistyk urodził się ok. 690 r. w wiosce Ardamut w ziemi Bet Nuhadra (obecnie w północno-zachodnim Iraku) blisko gór Kurdystanu? ${ }^{7}$ W lokalnym kościele studiował Pismo Święte, liturgię i pisma Ojców, przygotowując się do podjęcia życia monastycznego. Wstąpił do klasztoru Mar Yuzadak w górach Qardu blisko Turcji, gdzie przebywał siedem lat. Następnie za pozwoleniem przełożonych udał się w góry Dalijata i żył tam jako pustelnik. O tych górach wspomina tylko raz w pięknej biblijnej metaforze ${ }^{8}$. Przed śmiercią (780/786) z powodu osłabienia organizmu wrócił do Qardu i został przełożonym wspólnoty mnichów. Jest autorem m.in. Listów i Kazań. W tych pierwszych zwraca się do anonimowych adeptów ascezy monastycznej na różnym poziomie wtajemniczenia i stara się opisać osobiste doświadczenia życia mistycznego w odpowiedzi na ich pytania ${ }^{9}$. Zbiór 51 listów zawiera bogaty materiał z zakresu teologii duchowości nestoriańskiej: w studium psychologiczne wplecione są modlitewne hymny ${ }^{10} \mathrm{ku}$ czci Trójcy Świętej. Wydaje się, że kolejność tych listów jest dowolna; trudno zauważyć w niej logiczne uporządkowanie. Najprawdopodobniej Autorowi nie zależało na pisaniu podręcznika mistyki, ani na systematycznym wykładzie. Sam zresztą często podkreśla okazjonal-

of the Syriac Heritage, ed. S.P. Brock - A.M. Butts - G.A. Kiraz - L. Van Rompay, Piscataway 2011, 441-442; Jésusdenah, Évêque de Baçrah [AU: Ishō děnah, Bp of Basra], Liber castitatis, ed. J.-B. Chabot: Le Livre de la Chasteté, Rome 1896, 55-56; A. Baumstark, Geschichte der syrischen Literatur mit Ausschluß der christlich-palästinensischen Texte, Bonn 1922, 225-226; Bibliotheca hagiographica orientalis, ediderunt Socii Bollandiani, Subsidia Hagiographica 10, Bruxellis 1910, 114 [510]. W. Wright (A Short History of Syriac Literature, London 1894, 109-110, nota 1) podaje kilka analiz filologicznych przydomka Jana; w jednej z nich pojawia się wersja „Jan z żylakami”.

${ }^{7}$ Bet Nuhadra (Beth-Nouhadra) to dzisiaj uniwersyteckie miasto Dohuk w irackim Kurdystanie.

${ }^{8}$ Por. Joannes de Dalyatha, Epistula 37, 2, ed. Hansbury, s. 155.

${ }^{9}$ Por. tenże, Epistula 1, 2, ed. Hansbury, s. 5, tłum. własne: „Mój mistrzu, ojcze świętych”; tenże, Epistula 50, 1, ed. Hansbury, s. 233, tłum. własne: „Mój bracie, prosiłeś mnie, abym ci napisał...”. Por. R. Beulay, Jean de Dalyatha, DSp VIII 449-452; Z. Pałubska, Jan Saba, Jan z Daljata, zw. Starcem, EK VII 931.

${ }^{10}$ Por. Joannes de Dalyatha, Epistula 42, Modlitwa, ed. Hansbury, s. 191, thum. własne: „O, Chryste, Oceanie miłosierdzia! Niech ten brud, który mnie pokrywa, oczyści się w Tobie, aby moja szata lśniła świętością Twojej światłości. I aby okrył mnie obłok Twojej ukrytej chwały i ukrytych tajemnic (مוֹi)”; tenże, Epistula 31, 2, ed. Hansbury, s. 135, tłum. własne: „Chwała Tobie, który jednoczysz kochających Go, aby oni mogli być jedno z Nim w Jego Ojcu”; tenże, Epistula 38, 3, ed.

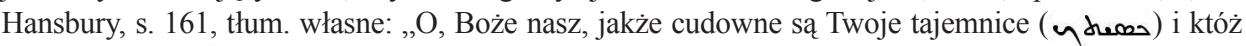
może je zgłębić (دمهم)!”; tenże, Epistula 51, 2, ed. Hansbury, s. 245, tłum. własne: „Błogosławiony ten, kto wpatruje się w Ciebie nieustannie, o Raju, który ukazujesz mi siebie we mnie! O, drzewo życia, Ty rozpalasz moje serce $(ل ص)$ w każdej chwili pragnieniem Ciebie i zmieniasz moje oblicze mocą Twojej miłości. Ty trzymasz mojego ducha ( piękna. Błogosławiony jest ten, kto szuka Ciebie zawsze w sobie. I to z Niego płynie życie dla jego

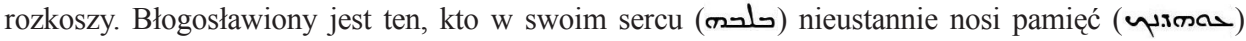
o Tobie, dlatego to jego dusza ( w Ciebie nieustannie w swoim wnętrzu. Jego serce (لحم) jest rozświetlone tak, że widzi to, co ukryte.

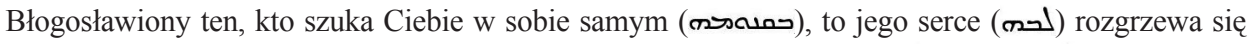

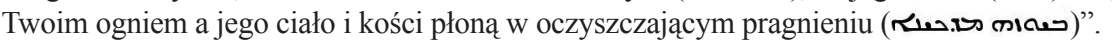


ną inspirację chwytania za pióro, którą była potrzeba rozwiania wątpliwości jego korespondentów ${ }^{11}$. Zdaniem Zofii Pałubskiej styl Jana jest chaotyczny, co miałoby zdradzać brak wykształcenia ${ }^{12}$. Tytuły listów zostały nadane najprawdopodobniej przez innego autora ${ }^{13}$.

W historii badań życia i dzieł Jana Saby należy wspomnieć problem wątpliwości, jakie powstały w jednoznacznej identyfikacji jego osoby. Źródłem zamieszania stały się odkrywane od XV w. różnorodne manuskrypty, w których imię Jan z przydomkiem Starzec mogło być kojarzona albo z osobą Jana bar Penkaje albo z osobą Jana z Dalijata. Zwolennicy przeciwstawnych interpretacji przedstawiali źródłowe argumenty ${ }^{14}$. Zdaniem Briana Collessa Jan z Dalijata i Jan bar Penkaje mogą być jedną i tą samą osobą ${ }^{15}$. Obecnie dominuje opinia, zgodnie z którą Jana Sabę identyfikuje się z Janem z Dalijata ${ }^{16}$.

2. Kontekst historyczno-teologiczny. Mistyczna doktryna Jana z jej specyfiką trynitarną i chrystologiczno-pneumatologiczną jest istotnym elementem osiagnięć tworzących ,złoty wiek" w rozwoju literatury wschodnio-syryjskiej od VI do VIII wieku ${ }^{17}$. Do grona czołowych przedstawicieli tego okresu zaliczają się także: Abraham z Natpar (VI w.), Martyrius Sahdona (VII w.), Dadisho Qatraya (VII w.), Izaak z Niniwy (VII w.), Symeon Taibuta (VII-VIII w.) i Józef Hazzaya. Jak wyjaśnić pojawienie się w stosunkowo krótkim okresie czasu tak wielu mistrzów życia duchowego? Czy wspólne cechy ich doktryny są jedynie wynikiem zbiegu okoliczności, czy można je uznać za przejaw programowo i świadomie działającej ,szkoły”? Zagadnienie precyzyjnej charakterystyki tego zjawiska pozostaje ciagle przedmiotem dyskusji ${ }^{18}$.

${ }^{11}$ Por. tenże, Epistula 25, 1, ed. Hansbury, s. 11. Charakter argumentacji zastosowanej przez Jana w Listach przybliża termin rłoasd (tahwwythā) thumaczony jako demonstratio. Zob. A. Uciecha, Kłooud (tahwaythā) jako metoda egzegetyczna w pismach Afrahata, perskiego Mędrca, BPTh 8 (2015) fasc. 1, 65-80.

${ }^{12}$ Por. Pałubska, Jan Saba, s. 931.

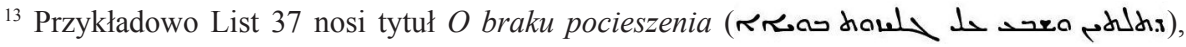
por. ed. Hansbury, s. 155; ed. Beulay, s. 43.

${ }^{14}$ Wnikliwe studium historii badań nad lustracją osoby Jana Saby przeprowadził R. Beulay, Précisions touchant l'identité et la biographie de Jean Saba de Dalyatha, ParOr 8 (1977-1978) 87-116.

${ }^{15}$ Por. B.E. Colless, The biographies of John Saba, ParOr 3 (1972) nr 1, 61-63; J. Jansma, Projet d'édition du Ke tābā deēess mellē de Jean bar Penkayé, OrSyr 8 (1963) 87-106; A. Vööbus, Syrische Kanonessammlungen: Ein Beitrag zur Quellenkunde, I: Westsyrische Originalurkunden, CSCO 307, Subsidia 35, Louvain 1970, 344-345.

${ }^{16}$ Por. Beulay, Précisions touchant, s. 87-116; M. Starowieyski, Jan z Dalijata, SWP 115.

${ }^{17} \mathrm{~W}$ badaniach historii nestoriańskiego monastycyzmu termin ,złoty wiek literatury wschodniosyryjskiej" obejmuje różny przedział czasowy. Por. H. Alfeyev, The Spiritual World of Isaac the Syrian, Cistercian Studies Series 175, Kalamazoo (Mi) 2000; V. Berti, Le Débat sur la Vision de Dieu et la Condamnation des Mystiques par Timothée Ier: La perspective du patriarche, w: Les mystiques syriaques, éd. A. Desreumaux, Études Syriaques 8, Paris 2011, 151.

${ }^{18}$ Por. S. Chialà, Les mystiques syro-orientaux: une école ou une époque?, w: Les mystiques syriaques, s. 63-78. Bogatą bibliografię historii badań specyfiki i przyczyn zadziwiającego rozwoju 
Kolejna uwaga wprowadzająca ma charakter metodologiczny i wydaje się konieczna w próbie prawidłowego zrozumienia istoty duchowości nestoriańskiej, jej rozwoju i wpływu, jaki wywarła na późniejsze epoki i wielkich mistyków. Otóż należy pamiętać, że nurt mistyczny pojawił się w duchowości nestoriańskiej na początku VII w., gdy tymczasem owa duchowość istniała już i rozwijała się wcześniej. Nurt ten nie ma charakteru jednorodnego. Silne oddziaływanie aleksandryjskiej tradycji teologicznej rodziło opór w Kościele nestoriańskim. Pierwotna duchowość syryjska wyrażała się przede wszystkim $\mathrm{w}$ ascezie i surowych praktykach pobożnych, natomiast akcentowanie doświadczenia wizji Boga w wewnętrznym duchowym oświeceniu budziło podejrzliwość. Jądrem sporu między tymi dwoma ujęciami była kwestia widzenia Boga. O wadze konfliktu może świadczyć stanowisko, jakie pod koniec VIII w. zajął Tymoteusz I. Na synodzie w 790 r. zwołanym przeciwko mistykom, oskarżanym o mesalianizm (Jan z Dalijata, Jan z Apamei i Józef Hazzaya $)^{19}$ ten patriarcha Ktezyfontu i Bagdadu oświadczył, że człowieczeństwo Chrystusa nie jest w stanie widzieć Jego bóstwa ${ }^{20}$.

W teologii nestoriańskiej centralnym punktem była transcendencja Boga i jej obrona przed wszelkim zmieszaniem z tym, co stworzone i ograniczone. Konsekwencje radykalnej przepaści w komunikacji między naturą ludzką i boską w osobie samego Chrystusa przechodziły w sposób oczywisty na duchowość świętych i determinowały ich ograniczone możliwości zjednoczenia z Bogiem ${ }^{21}$. Należy jednak zaznaczyć, że w trudne kontrowersje mistycznego oglądania Boga Jan potrafił wprowadzić wątki pozytywne. Jako ortodoksyj-

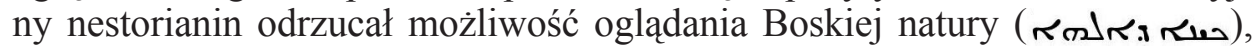
identyfikowanej jako transcendentna Istota Ojca, natomiast akceptował real-

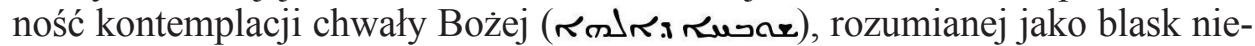
widzialnej natury. Wydaje się, że Jan z Dalijata jest jedynym wśród wszystkich

teologii duchowości w okresie od VI do VIII w. w środowisku syro-orientalnym znajdziemy w opracowaniu G. Kessel - K. Pinggéra, A Bibliography of Syriac Ascetic and Mystical Literature, Eastern Christian Studies 11, Leuven 2011, 13-16; B.E. Colles, The Wisdom of the Pearlers. An Anthology of Syriac Christian Mysticism, Cistercian Studies Series 216, Kalamazoo (Mi) 2008.

${ }^{19}$ Por. Berti, Le Débat sur la Vision de Dieu, s. 151-176; M. Starowieyski, Jan z Apamei [w Syrii lub Mezopotamii], SWP 111; H. Labourt, De Timotheo I, Nestorianorum patriarcha (728823), et christianorum orientalium condicione sub caliphis Abbasidis: accedunt XCIX ejusdem Timothei definitiones canonicae, e textu Syriaco inedito latine redditae, Paris 1904, 20; M. Kmosko, Praefatio-Caput IV. Res gestae messalianorum inter nestorianos, w: Liber graduum, PSyr 1/3, Paris 1926, CXXX.

${ }^{20}$ Por. A. Mingana, Early Christian Mystics, Woodbrooke Studies 7, Cambridge 1934, syr. 289290, ang. 21; O. Braun, Zweit Synoden des Catholikos Timotheo I, OC 2 (1902) 304-308; A. Treiger, Could Christ Humanity see his Divinity? An Eight Century Controversy between John of Dalyatha and Timothy I, Catholicos of the Church of the East, „Journal of the Canadian Society for Syriac Studies" 9 (2009) 3-21.

${ }^{21}$ Por. R. Beulay, Originalité de Jean Dalyatha dans la spiritualité syro-orientale, w: Le Monachisme Syriaque du VII siècle à nos jours, vol. 1, Patrimoine Syriaque. Actes du colloque 6, Antélias (Liban) 1999, 142. 
mistyków, nie tylko syro-orientalnych, który starał się wyjaśnić to rozróżnienie w kontekście biblijnym myśli św. Pawła: „My wszyscy z odsłoniętą twarzą wpatrujemy się w jasność Pańską jakby w zwierciadle; za sprawą Ducha Pańskiego, coraz bardziej jaśniejąc, upodabniamy się do Jego obrazu" (2Kor $3,18)$ i „Albowiem Bóg, Ten, który rozkazał ciemnościom, by zajaśniały światłem, zabłysnął w naszych sercach, by olśnić nas jasnością poznania chwały Bożej na obliczu Chrystusa" (2Kor 4, 6). Chwała Boża widoczna jest i możliwa do ujrzenia na obliczu Chrystusa, natura Boska zaś nie może być widoczna. W swoim oryginalnym ujęciu mistyki Jan odkrywa dialektyczne relacje między tymi dwoma wymiarami boskości: naturą i chwałą. Zadanie wytyczenia granicy między nimi wydaje się niemożliwe, gdyż trudno uchwycić moment transformacji Boskiej natury, czyli transcendencji i nieskończoności Boga w chwałę Bożą, w której Bóg dostosowuje się do możliwości człowieka. Wejście w tajemnicę chwały Bożej jest procesem nieustannym i nie ogranicza się tylko do doczesności. Możliwe, że w tym punkcie teologii mistycznej Jan przejął intuicję przebóstwienia i nieograniczonego postępu w poznawaniu Bożych tajemnic Grzegorza z Nyssy, próbując wyjaśniać Pawłowe „coraz bardziej jaśniejąc" 22 . W duchowym procesie nieustannego rozwoju granica między tymi atrybutami boskości stale się przesuwa ku nieskończonej głębi boskiej natury. Bóg pozwala kontemplować ustawicznie blask swojej chwały. To niekończące się odkrywanie Boga i przekraczanie, a raczej przesuwanie, granicy poznania, rodzi zachwyt w człowieku. Jan mówi o ciemności, która staje się coraz bardziej jasna, i o świetle, które gaśnie coraz bardziej. Jednak zarówno w świetle, jak i w ciemności człowiek rozpoznaje Boże zaproszenie, gdyż źródłem tego duchowego rozwoju jest Duch Swięty, ożywcze Tchnienie Ojca.

Droga, która prowadzi do tego mistycznego doświadczenia jest modlitwa serca $^{23}$. Jan nie używa dosłownie tego wyrażenia, ale chętnie cytuje biblijne teksty podkreślające znaczenie wnętrza i serca człowieka w jednoczeniu się

${ }^{22}$ Por. Gregorius Nyssenus, In Canticum canticorum, ed. H. Langerbeck, GNO 6, Leiden 1960 , thum. M. Przyszychowska: Grzegorz z Nyssy, Homilie do Pieśni nad Pieśniami, ŹMT 43, Kraków 2007. Zob. A. Eckmann, Przebóstwienie człowieka w pismach wczesnochrześcijańskich, Lublin 2003; S. Strękowski Sofiologia św. Grzegorza z Nyssy. Elementy teologii trynitarnej i antropologii w „Homiliach do Pieśni nad Pieśniami”, Kraków 2006.

${ }^{23}$ Por. Joannes de Dalyatha, Epistula 13, O pokorze i postuszeństwie (Rhausdrsa הah), ed. Hansbury, s. 266, thum. własne: „Nieustannie wysławiaj swoim sercem i we

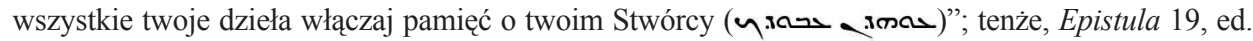
Hansbury, s. 270, tłum. własne: „Przed wszystkim i we wszystkim przestrzegam cię, abyś nie pozwolił umierać życiu, to znaczy aby twoje serce (لحصu) nigdy nie było pozbawione pamięci o twoim Panu

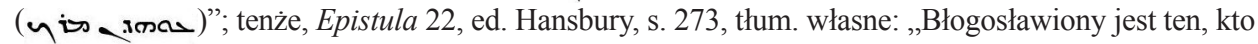

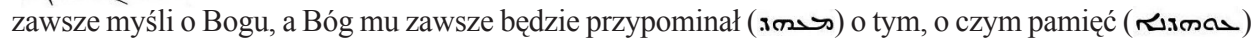
nie wspomina w jego umyśle (por. 1Kor 2, 9)". 
z Bogiem: Mt 5, 824; Łk 17, 2125; J 7, 38 26; Rz 8, 927; 1Kor 3, 16 28; 2Kor 4, $6^{29}$; Ef $1,18^{30} ; 2 \mathrm{P} 1,19^{31}$. Oprócz konfrontacyjnych elementów względnej kontestacji oficjalnej nauki Kościoła nestoriańskiego w strukturze oryginalnej myśli Mistyka z Dalijata można dostrzec wyraźne wpływy Pseudo-Makarego ${ }^{32}$, Pseudo-Dionizego Areopagity ${ }^{33}$, Ewagriusza z Pontu i wspomnianego już Grzegorza z Nyssy ${ }^{34}$. Jan zasymilował bogactwo teologii duchowości tych mistrzów, zwłaszcza „pneumatyczne nachylenie" charakterystyczne dla mistyki Pseudo-Makarego. Instrumentami jego twórczej adaptacji tego dziedzictwa były intuicyjna zdolność oddzielania tego, co istotne, od tego, co tylko przypadkowe, umiejętność selekcjonowania danych i ich waloryzacji na podstawie własnego doświadczenia, sztuka aplikacji trafnych porównań i terminologii pełnej paradoksów ${ }^{35}$.

Należy także pamiętać, że w dziełach syro-orientalnych mistyków nie występuje termin „doświadczenie mistyczne”. Ekwiwalentem tego określenia

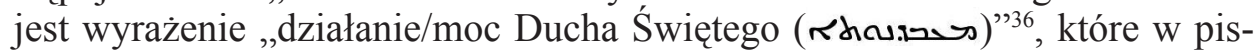

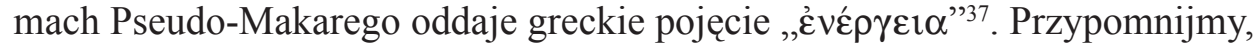
że mistycy wschodnio-syryjscy nie znają określenia „modlitwa serca”, chętnie zaś używają innego wyrażenia, któremu warto się przyjrzeć bliżej.

\footnotetext{
${ }^{24}$ Por. tenże, Epistula 14, 2, ed. Hansbury, s. 69.

${ }^{25}$ Por. tenże, Epistula 39, 1, ed. Hansbury, s. 163.

${ }^{26}$ Por. tenże, Epistula 51, 2, ed. Hansbury, s. 245.

${ }^{27}$ Por. tenże, Epistula 39, 2, ed. Hansbury, s. 165.

${ }^{28}$ Por. tenże, Epistula 44, 3, ed. Hansbury, s. 213.

${ }^{29}$ Por. tenże, Epistula 12, 4, ed. Hansbury, s. 59.

${ }^{30}$ Por. tenże, Epistula 47, 1, ed. Hansbury, s. 223.
}

${ }^{31}$ Por. tenże, Epistula 44, 2, ed. Hansbury, s. 211. Zob. R. Beulay, L'enseignement spirituel de Jean de Dalyatha, mystique syro-oriental du VIII siècle, Théologie historique 83, Paris 1990, 143.

${ }^{32}$ Wpływ „wyczulenia symbolicznego” (sensibilité symbolique) Pseudo-Makarego na swoistą obrazowość wypowiedzi Jana z Dalijata sygnalizuje N. Khayyat, La liturgie mystiques des Moines syro-orientaux, w: Le Monachisme Syriaque. Aux premiers siècles de l'Eglise, II' - début VII' siècle, vol. 1, Patrimoine Syriaque. Actes du colloque 5, Antélias (Liban) 1998, 244, nota 4.

${ }^{33}$ Polycarpe Sherwood (Influence du Pseudo-Denys en Orient, DSp III 286-288) minimalizuje wpływ Pseudo-Dionizego Areopagity na syro-orientalną teologię mistyczną. Por. É. Des Places, La Préparation du Platonisme Médiéval. Le pseudo-Denys l'Aréopagite, ses précurseurs et sa postérité, w: tenże, Études platoniciennes 1929-1979, Leiden 1981, 379; Jean de Dalyatha, Les Homélies $I-X V$, ed. Nadira Khayyat, Sources syriaques, Antélias (Liban) 2007.

${ }^{34}$ Por. Y. de Andia, Introduction, w: Pseudo-Denys l'Aréopagita, Les Noms Divins I-IV, ed. Y. de Andia, SCh 578, Paris 2016, 168-169; Colles, The Wisdom of the Pearlers, s. 21-39.

${ }^{35}$ Por. Beulay, Originalité de Jean Dalyatha, s. 141-147; tenże, Doit-on, avec les SyroOrientaux, considérer la vie monastique comme la condition nécessaire de l'expérience mystique?, w: Le Monachisme Syriaque. Aux premiers siècles de l'Eglise, II - début VIle siècle, s. 235-241.

דרבזיטהאR : ${ }^{36}$ Por. Thesaurus Syriacus, ed. R. Payne Smith, t. 2, Oxonii 1901, 2776-2777 - „operatio”, „efficientia”, „activitas”.

${ }^{37}$ Por. Pseudo-Macarius, Homiliae 7, 3, 18, ed. V. Desprez, SCh 275, Paris 1980, 122; 7, 6, 39,

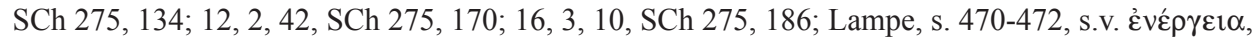
$\dot{\eta}$, activity, operation, performance, actuality. 
3. „Pamięć o Bogu” (حח). W bogactwie wielowątkowej mistyki Jana Saby zwraca uwagę interesujący fenomen, ukryty w często pojawiającym się określeniu ,pamięć o Bogu” (حח (

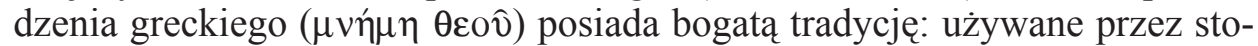
ików, znane z opisu ascezy terapeutów Filona Aleksandryjskiego, pomyślnie zaadaptowane w chrześcijańskiej literaturze monastycznej (Ewagriusz z Pontu, Bazyli Wielki, Teodoret z Cyru, Pseudo-Makary, Abba Marek, Abba Izaja$\mathrm{sz})^{38}$. Uwzględniając stylistyczną różnicę ujęcia między Listami a Kazaniami, wydaje się bardziej celowe zbadanie znaczenia i zakresu tego wyrażenia używanego w bardziej personalnym dyskursie Listów.

W jaki sposób Jan z Dalijata interpretuje zjawisko „pamięć o Bogu”? Jakie wątki teologiczne i antropologiczne składają się na ten zagadkowy element mistycznego doświadczenia?

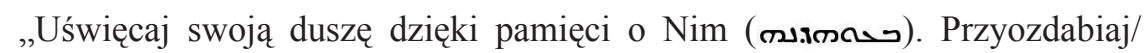
oczyszczaj ( Jego miłości: dzięki temu On sam ukaże się tobie i uraduje ciebie Jego widzeniem (rsilu). To ona [miłość] sprawi, że On zamieszka w twojej duszy ze swoim Ojcem i swoim Duchem (por. J 14, 17.23). To ona [miłość] sprawi, że ty sam staniesz się jakby obrazem Jego samego (במו אמw) i na wszystkie strony będziesz widział wyraźnie. Dzięki niej będziesz stąpał w głębinach, a w jej świetle ujrzysz najwyższe nieba. To ona wypełni ciebie tajemnicami Ducha i objawi ci niestworzone światło, i wskaże ci jak w nim kroczyć (por. 1J 1, 7; Ps 89, 16). Dzięki niej to wszystko, co jest w tobie, będzie promieniować blaskiem. I to wszystko, co jest przed tobą, zajaśnieje światłem. Ona uczyni cię królem zamiast niewolnikiem i położy wszystkich twoich nieprzyjaciół pod twoje stopy, abyś [po nich] stąpał. To ona uwieńczy twój rozum wieńcem wręczanym na koniec biegu (por. $2 \mathrm{Tm} 4,7-8$ ), i w poruszeniach twojego rozumu ukaże się kontemplacja Świętej Trójcy. Dlatego zakończmy te nasze słowa w tym schronieniu wszystkich światów. Niech On będzie uwielbiony ponad wszystko. Amen"39.

Pojęcie „pamięć o Bogu” ma tutaj znaczenie pozytywne ${ }^{40}$ i oznacza przemieniającą modlitwę nakierowaną ku Bogu obecnym w duszy człowieka modlącego się. Mistyk z Dalijata nie mówi wprost ani o memoryzacyjnej strategii powtarzania modlitewnych wezwań, ani o dyscyplinie oddechu, ale akcentuje walor interioryzacji modlitwy. Proces ten przebiega w kilku etapach. Na

\footnotetext{
${ }^{38}$ Por. Beulay, Originalité de Jean Dalyatha, s. 145-146.

${ }^{39}$ Joannes de Dalyatha, Epistula 15, 10, ed. Hansbury, s. 81, thum. własne.

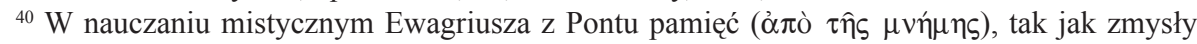

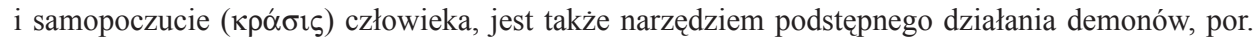
Evagrius Ponticus, De malignis cogitationibus 4, PG 79, 1204D, tłum. L. Nieścior: Ewagriusz z Pontu, $O$ różnych rodzajach złych myśli, w: Ewagriusz z Pontu, Pisma ascetyczne, t. 1, ŹM 18, Kraków 20072, 332-333.
} 
wstępie należy skierować duchowy wzrok, inaczej ducha, który jest witalną siłą ukrytą w głębi każdej osoby do wnętrza, w którym przebywa Bóg. Główną siedzibą ,pamięci o Bogu” jest ludzkie serce. To centrum duchowości człowieka rejestruje bodźce intelektualne i emocjonalne. W sercu człowieka przebywa Duch Święty i tam spotyka on Boga ${ }^{41}$. W całej tradycji syro-orientalnej serce człowieka jest punktem kontaktowym między ciałem i duszą. Ukierunkowane działanie wzroku oznacza skupienie wszystkich elementów ludzkiej istoty w stanie najwyższej czujności. Dzięki swojej dynamicznej zdolności duch przechodzi na drugi etap modlitwy. Mistyk doświadcza spokoju i błogości, chociaż duch pozostaje jeszcze jakby w przedsionku serca. Drzwi uchylają się stopniowo i z wnętrza wyłania się blask chwały Bożej. To na tym poziomie rozpoczyna się nieustanny proces wyrażony przez św. Pawła słowami „coraz bardziej jaśniejąc". Ciasne i ograniczone ludzkie wnętrze przechodzi metamorfozę i powiększa swoją duchową przestrzeń w miarę jak coraz bardziej spotyka/ogląda Boga. Proces duchowej percepcji przyspiesza i modlący się osiagga kolejny poziom otwarcia na dotychczas niezauważane bodźce. Kulminacyjnym momentem procesu interioryzacji modlitwy jest duchowa przemiana całego człowieka i możliwość kontemplacji tajemnic Trójcy Świętej.

W strukturze duchowego życia mnicha Jan z Dalijata wyszczególnia trzy stopnie działania Ducha Świętego: na pierwszym etapie realna i subtelna pomoc Ducha Świętego pozostaje ukryta, a realizuje się w praktykach ascetycznych. Na drugim stopniu Jego działanie rodzi usposobienie odpoczynku i pocieszenia. W końcu mistyk stopniowo doświadcza cudownych wizji i objawień, w których ogląda blask chwały Bożej i sam tą chwałą promienieje.

W koncepcji duchowości wschodnio-syryjskiej doświadczenie mistyczne zarezerwowane było dla mnichów, zwłaszcza eremitów. Prawdopodobnie ten ekskluzywizm miał swoje źródło w mocno akcentowanym dualizmie trosk doczesnego świata i wolności doświadczenia duchowego i w uwrażliwieniu na ciagle żywe w Mezopotamii i niebezpieczne zwłaszcza dla monastycyzmu tendencje gnostyckie. Dla wschodnich Syryjczyków doświadczenie mistyczne uwarunkowane było wymaganiem życia w samotności, a prawdziwym chrześcijaninem był mistyk ${ }^{42}$. Jakie zdanie ma w tej kwestii Jan z Dalijata?

Ten kto nie zobaczył w sobie samym blasku Bożej chwały, powie Saba, „ciagle przebywa pośród zmarłych" ${ }^{43}$. Mistyk z Dalijata podkreśla bezmiar miłości Boga i Jego łaskawości względem człowieka. Dlatego ubolewa nad faktem, że tak niewielu dostrzega niezliczone znaki, w których Bóg objawia

${ }^{41}$ Por. ed. Hansbury, s. 232, nota 3. Komentarz na temat Chrystusowego polecenia modlitwy „w izdebce” (Mt 6, 6), zob. Aphraates, Demonstratio 4, 10, ed. J. Parisot: Aphraatis Sapientis Persae Demonstrationes, PSyr 1, 157, 10 - 160, 19, thum. A. Uciecha: Afrahat, O modlitwie (Demonstratio quarta. De oratione, PSyr 1, 137-182), ŚSHT 43 (2010) fasc. 1, 39. Por. P. Brock, Spirituality of the Heart in Syriac Tradition, Harp 1 (1988) 93-115.

${ }^{42}$ Por. A. Guillaumont, Syriaque (Spiritualité), DSp XIV 1430.

${ }^{43}$ Por. Joannes de Dalyatha, Epistula 2, 7, ed. Hansbury, s. 17. 
swoją chwałę ${ }^{44}$. To ograniczenie nie wynika z Bożej obojętności na ograniczoność ludzkiej percepcji, ale z dobrowolnego wyboru człowieka.

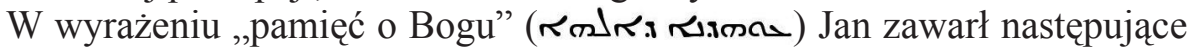
mistyczne treści: nieustanne skupienie na $\mathrm{Bogu}^{45}$, wdzięczną chwałę ${ }^{46}$, czystą intencję $\mathrm{w}$ rozeznawaniu ${ }^{47}$, medytację $\mathrm{z}$ wykorzystaniem wyobrażeń ${ }^{48}$. Zdaniem Roberta Beulaya najbardziej oryginalne znaczenie pojęcia „pamięć o Bogu" ukrywa się w prostym działaniu polegającym na nieustannym poszukiwaniu Boga w głębi serca i niezmiennym wpatrywaniu się (riav) w Niego bez końca ${ }^{49}$. „Pamięć o Bogu” ( się w Niego ${ }^{50}$.

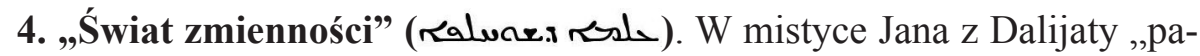

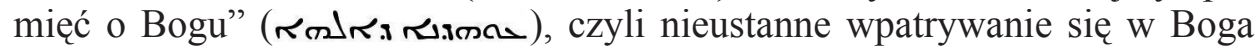
i poszukiwanie Go w głębi serca, jest koniecznym warunkiem w procesie rozwoju wrażliwości mistycznej. Na drodze realizacji tego ambitnego postulatu stają różne przeszkody. Jan odpowiada na pytanie swojego mistrza duchowego, który interesował się wewnętrzną kondycją swojego ucznia. W mistycznych kontaktach z Bogiem największą przeszkodą jest wszelka zmienność, brak stałości (ralur r $^{51}$. Jan wnikliwie charakteryzuje bolesne doświadczenie wewnętrznego rozdarcia. Mistyk raz jest pełny życia, innym razem znowu „,śmierć walczy ze mną w moich członkach”. Raz pokonuje swoje namiętności, innym razem to demony śmierci zwyciężają. Raz ucieka od ludzi i jednoczy

${ }^{44}$ Por. tenże, Epistula 5, 4, ed. Hansbury, s. 36.

${ }^{45}$ Por. tenże, Epistula 50, 1, ed. Hansbury, s. 233, tłum. własne: „Mój bracie, prosiłeś mnie, abym ci napisał na temat tej kontemplacji Boga (הכאלח א

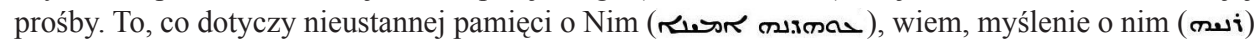

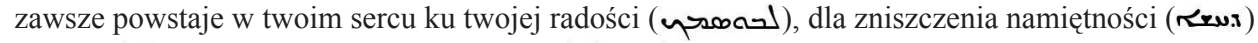

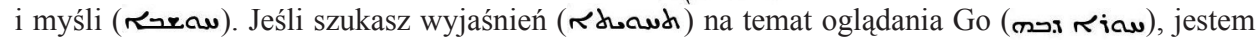

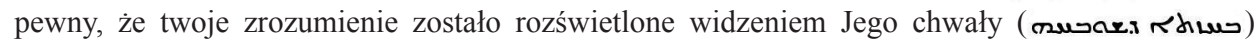
i przekroczyło wszelką potrzebę [udzielania] wskazówek (مaud)".

${ }^{46}$ Por. tenże, Epistula 4, 1, ed. Hansbury, s. 21, tłum. własne: „Uwolnij twoją duszę (4ra) od

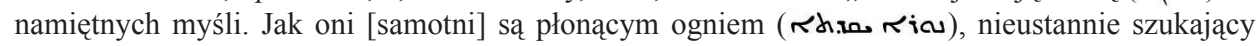
Boga, podobnie też niech będzie twoje spojrzenie nieustannie skierowane na Niego w uwielbianiu

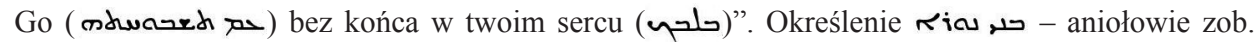
L. Costaz, Syriac - French - English - Arabic Dictionary, Beyrouth 19862, 200.

${ }^{47}$ Por. Joannes de Dalyatha, Epistula 13, 19, O pokorze i postuszeństwie, ed. Hansbury, s. $267-271$.

${ }^{48}$ Por. tenże, Epistula 50, 2, ed. Hansbury, s. 233.

${ }^{49}$ Por. Beuley, L'enseignement spirituel de Jean de Dalyatha, s. 126.

${ }^{50}$ Por. Joannes de Dalyatha, Epistula 50, 6, ed. Hansbury, s. 235, thum. własne: „Jeśli moc

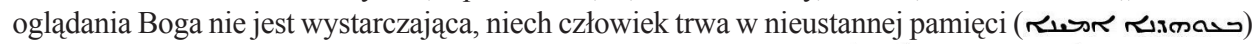

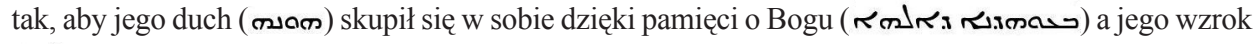
(Rin) był [skierowany] na Niego".

${ }^{51}$ Por. Thesaurus Syriacus, ed. R. Payne Smith, t. 1, Oxonii 1879, 1290: Raluar - ,variatio, mutatio". 


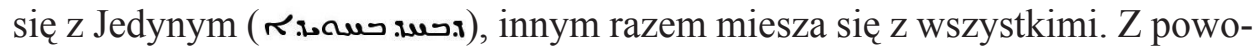
du uciążliwej zmienności trudno jest Mistykowi nazwać i opisać wewnętrzny

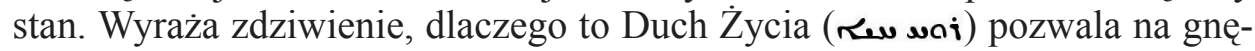
biące mnicha ataki śmierci. Tenże Duch działa całkowicie celowo: chce w ten sposób przestrzec mnicha przed „zachłystywaniem się oddechem śmierci” 52 . Wewnętrzna zmienność oznacza destabilizację w procesie oczyszczającego rozświetlania duszy w Chrystusie, czyli w „odblasku Bożej chwały” (por. Hbr $1,3)$. Powstają wtedy komplikacje w odkrywaniu ukrytych tajemnic Ducha ${ }^{53}$.

„Jednak dlatego, że żyjemy w świecie zmienności (حلدئr) i z powodu chwilowych nieszczęść, pokus i upominającego działania Opatrzności (ruanol rowina), czasem pamięć o Bogu ( ta z naszego serca, a nasza dusza (sa) traci Jego wizję (mdiw) i zapominamy

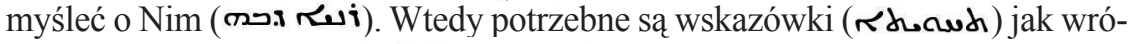

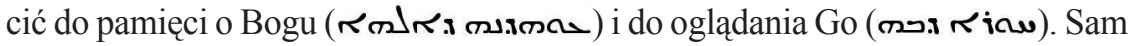
jestem słaby i chcę przekazać wskazówki tym, którzy jak ja są słabi, aby dzięki

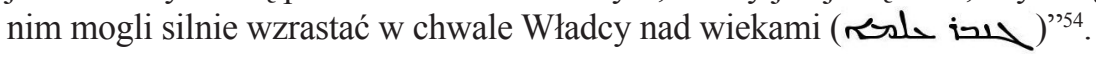

Rzetelność relacji Mistyka świadczy o tym, że opisuje on własne doświadczenie duchowe wypracowane latami. Osiagnięcie wewnętrznej stabilizacji nie jest stanem, który zdobywa się raz na zawsze, lecz raczej usposobieniem, które można utracić. Doczesność jest zmienna i wypełniona różnymi nieszczęściami. Mnich traci wtedy „pamięć o Bogu”. Saba podejmuje wątek nawrócenia, w którym ważną rolę gra świadectwo autorytetu. Wskazówki doświadczonego mentora i jego obecność wydają się niezbędne, aby przywrócona została możliwość oglądania „Władcy nad wiekami” i to nie tylko w doczesności, ale przede wszystkim w wieczności. Istotnym elementem duchowej rewitalizacji osłabionej wrażliwości mistycznej jest pokora i świadomość ludzkiej słabości.

$$
* * *
$$

W artykule podjęto próbę zarysowania konturów teologii mistycznej nestoriańskiego mnicha Jana z Dalijata (Jan Saba lub Starzec) żyjącego na przełomie VII i VIII w. na pograniczu dzisiejszej Turcji i Iraku. Jego twórczość zawarta w Listach i Kazaniach wpisuje się w osiagnięcia ,złotego wieku” chrześcijańskiej literatury wschodnio-syryjskiej. Zgodnie z prawdami nestoriańskiej ortodoksji Saba odrzucał możliwość oglądania Boskiej natury, którą to naturę identyfikował z transcendentną Istotą Ojca, natomiast akceptował realność kontemplacji chwały Bożej rozumianej jako blask i odbicie niewidzialnej natury. Jan z Dalijata jako jedyny wśród wszystkich mistyków starał się wyjaśnić to rozróżnienie w biblijnym kontekście myśli św. Pawła (2Kor 3, 18; 4, 6). W analizach

\footnotetext{
${ }^{52}$ Por. Joannes de Dalyatha, Epistula 37, 1, ed. Hansbury, s. 155.

${ }^{53}$ Por. tenże, Epistula 1, 1, ed. Hansbury, s. 4.

${ }^{54}$ Tenże, Epistula 50, 2, ed. Hansbury, s. 233, tłum. własne.
} 
treściowej zawartości jego mistycznego nauczania zasygnalizowano wątki

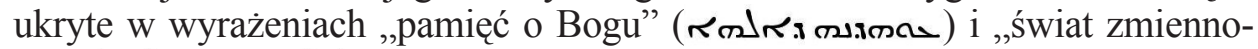
ści" (حلدى ). Nieustanne wpatrywanie się w Boga i poszukiwanie Go w głębi serca jest koniecznym warunkiem w procesie rozwoju wrażliwości mistycznej. Uderza psychologiczna głębia religijnych postulatów Jana. W ludzkiej duszy to serce jest miejscem zjednoczenia z Bogiem, podobnym do tego, jakim było „Święte Świętych” w przybytku. Jan przekazuje swoje duchowe doświadczenia, chociaż ma świadomość ułomności i ograniczoności w ludzkiej komunikacji Bożych tajemnic. Przedstawione opracowanie stanowi zaproszenie do dalszych badań nad nestoriańską teologią mistyczną Jana z Dalijata.

\section{THEOLOGICAL FUNDAMENTS OF THE NESTORIAN (EAST SYRIAN) MONASTIC MYSTICISM IN THE LETTERS OF JOHN OF DALYATHA}

\section{(Summary)}

The article attempts to draw an outline of the mystic theology of the Nestorian monk John of Dalyatha (John Saba, ,the Elder"), who lived at the border of what is now Turkey and Iraq at the turn of the 7th and the 8th centuries. His literary output consists of the letters and the homilies and belongs to the „golden age" of the East Syrian Christian literature. In line with the Nestorian Orthodoxy, John Saba denied the perception of the God's nature, which was identified by him with the transcendent nature of Father. He accepted, however, a contemplation of God's glory, understood as a radiance and a reflection of the invisible nature. John of Dalyatha was the only mystic who attempted to explain this distinction in the light of ideas of St. Paul (2Cor 3:18 and 4:6). The subject of the current analysis

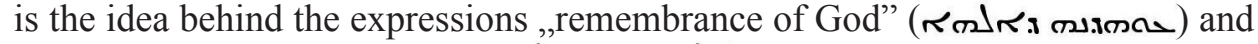
„the world of changeability” (حلدم (حلs). Unceasing looking at the God, and searching for Him deep into the heart is necessary for the development of mystical sensitivity. The psychological depth of John's religious programme is striking. In the human soul, the heart is the place of a union with the God, as it was in ,the Holy of Holies”. John conveys his spiritual experience, although he is fully conscious of imperfect means through which man can communicate the mysteries of God.

Key words: John of Dalyatha, Nestorianism, Syrian monasticism, East Syrian mysticism.

Słowa kluczowe: Jan z Dalijata, nestorianizm, monastycyzm syryjski, mistyka syro-orientalna. 


\title{
BIBLIOGRAFIA
}

\author{
Źródła
}

Aphrantes, Demonstrationes, ed. J. Parisot: Aphraatis Sapientis Persae Demonstrationes, PSyr 1, Paris 1894, 1980², PSyr 2, Paris 1907, 1980², tłum. A. Uciecha: Afrahat, O modlitwie (Demonstratio quarta. De oratione, PSyr 1, 137-182), ŚSHT 43 (2010) fasc. 1, 31-44.

Ephraem Syrus, Hymnus de fide 81 (De Margarita I), ed. E. Beck, CSCO 154, Scriptores Syri 73, Louvain 1955, 248-251, tłum. niemieckie E. Beck, w: Des Heiligen Ephraem des Syrers „,Hymnen de Fide”, CSCO 155, Scriptores Syri 74, Louvain 1955, 211-213.

Evagrius Ponticus, De malignis cogitationibus, PG 79, 1200-1233, tłum. L. Nieścior: Ewagriusz z Pontu, O różnych rodzajach złych myśli, w: Ewagriusz z Pontu, Pisma ascetyczne, t. 1, ŹM 18, Kraków 2007², 332-333.

Gregorius Nyssenus, In Canticum canticorum, ed. H. Langerbeck, GNO 6, Leiden 1960, tłum. M. Przyszychowska: Grzegorz z Nyssy, Homilie do Pieśni nad Pieśniami, ŹMT 43, Kraków 2007.

JÉsusdenAH, Évêque de Baçrah [AU: Ishōeděnah, Bp of Basra], Liber castitatis, ed. J.-B. Chabot: Le Livre de la Chasteté, Rome 1896.

JoAnNes De Dalyatha, Epistulae, ed. R. Beulay: La Collection des Lettres de Jean de Dalyatha, PO 39, fasc. 3 (180), Turnhout 1978; ed. M. Hansbury: The Letters of John of Dalyatha, Texts from Christian Late Antiquity 2, Piscataway 2006.

Joannes de Dalyatha, Homiliae I-XV, ed. N. Khayyat: Jean de Dalyatha, Les Homélies $I-X V$, Sources syriaques, Antélias (Liban) 2007.

Pseudo-Macarius, Homiliae, ed. V. Desprez, SCh 275, Paris 1980.

\section{Opracowania}

Alfeyev H., The Spiritual World of Isaac the Syrian, Cistercian Studies Series 175, Kalamazoo (Mi) 2000.

Berti V., Le Débat sur la Vision de Dieu et la Condamnation des Mystiques par Timothée $I^{e r}$ : La perspective du patriarche, w: Les mystiques syriaques, éd. A. Desreumaux, Études Syriaques 8, Paris 2011, 151-176.

Braun O., Zweit Synoden des Catholikos Timotheo I, OC 2 (1902) 304-308.

Baumstark A., Geschichte der syrischen Literatur mit Ausschluß der christlich-palästinensischen Texte, Bonn 1922.

Beulay R., Doit-on, avec les Syro-Orientaux, considérer la vie monastique comme la condition nécessaire de l'expérience mystique?, w: Le Monachisme Syriaque. Aux premiers siècles de l'Eglise, $I I^{e}$ - début VII siècle, vol. 1, Patrimoine Syriaque. Actes du colloque 5, Antélias (Liban) 1998, 235-241.

Beulay R., Jean de Dalyatha, DSp VIII 449-452.

BeUlay R., L'enseignement spirituel de Jean de Dalyatha, mystique syro-oriental du VIII siècle, Théologie historique 83, Paris 1990.

Beulay R., Originalité de Jean Dalyatha dans la spiritualité syro-orientale, w: Le Monachisme Syriaque du VII siècle à nos jours, vol. 1, Patrimoine Syriaque. Actes du colloque 6, Antélias (Liban) 1999, 141-147.

Beulay R., Précisions touchant l'identité et la biographie de Jean Saba de Dalyatha, ParOr 8 (1977-1978) 87-116. 
Bibliotheca hagiographica orientalis, ediderunt Socii Bollandiani, Subsidia Hagiographica 10, Bruxellis 1910.

Brock P., Spirituality of the Heart in Syriac Tradition, „Harp” 1 (1988) 93-115.

Chialà S., Les mystiques syro-orientaux: une école ou une époque?, w: Les mystiques syriaques, éd. A. Desreumaux, Études Syriaques 8, Paris 2011, 63-78.

Colless B.E., Yohannan of Dalyatha (8 ${ }^{\text {th }}$ centur.), w: Gorgias Encyclopedic Dictionary of the Syriac Heritage, ed. S.P.Brock - A.M. Butts - G.A. Kiraz - L. Van Rompay, Piscataway 2011, 441-442.

Colless B.E., The biographies of John Saba, ParOr 3 (1972) nr 1, 45-63.

Colless B.E., The Wisdom of the Pearlers. An Anthology of Syriac Christian Mysticism, Cistercian Studies Series 216, Kalamazoo (Mi) 2008.

Costaz L., Syriac - French - English - Arabic Dictionary, Beyrouth $1986^{2}$.

Eckmann A., Przebóstwienie człowieka w pismach wczesnochrześcijańskich, Lublin 2003.

Jansma J., Projet d'édition du Ketābā derēš mellē de Jean bar Penkayé, OrSyr 8 (1963) 87-106.

Kessel G. - Pinggéra K., A Bibliography of Syriac Ascetic and Mystical Literature, Eastern Christian Studies 11, Leuven 2011.

Khayyat N., La liturgie mystiques des Moines syro-orientaux, w: Le Monachisme Syriaque. Aux premiers siècles de l'Eglise, II - début VII siècle, vol. 1, Patrimoine Syriaque. Actes du colloque 5, Antélias (Liban) 1998, 243-249.

Kмоsко M., Praefatio-Caput IV. Res gestae messalianorum inter nestorianos, w: Liber graduum, PSyr 1/3, Paris 1926, CXXX-CXXXV.

Labourt H., De Timotheo I, Nestorianorum patriarcha (728-823), et christianorum orientalium condicione sub caliphis Abbasidis: accedunt XCIX ejusdem Timothei definitiones canonicae, e textu Syriaco inedito latine redditae, Paris 1904.

LAmpe G.W.H., A Patristic Greek Lexicon, Oxford 1978.

Mingana A., Early Christian Mystics, Woodbrooke Studies 7, Cambridge 1934.

PaŁubska Z., Jan Saba, Jan z Daljata, zw. Starcem, EK VII 931.

Places É. Des, Études platoniciennes 1929-1979, Leiden 1981.

Sherwood P., Influence du Pseudo-Denys en Orient, DSp III 286-318.

Słownik Wczesnochrześcijańskiego Piśmiennictwa, red. M. Starowieyski - J.M. Szymusiak, Poznań 1971.

StręKowski S., Sofiologia św. Grzegorza z Nyssy. Elementy teologii trynitarnej i antropologii w ,Homiliach do Pieśni nad Pieśniami”, Kraków 2006.

Thesaurus Syriacus, ed. R. Payne Smith, t. 1-2, Oxonii 1879-1901.

Treiger A., Could Christ Humanity see his Divinity? An Eight Century Controversy between John of Dalyatha and Timothy I, Catholicos of the Church of the East, ,Journal of the Canadian Society for Syriac Studies" 9 (2009) 3-21.

UCIECHA A., Egzegeza biblijna w komentarzach syryjskich Afrahata, Efrema, Iszdoada z Merw i Teodora Bar Koni. Zarys problematyki, VoxP 37 (2017) t. 67, 673-688.

UCIECHA A., గ九几uł (tahwaythā) jako metoda egzegetyczna w pismach Afrahata, perskiego Mędrca, BPTh 8 (2015) fasc.1, 65-80.

Wright W., A Short History of Syriac Literature, London 1894.

Vööвus A., Syrische Kanonessammlungen: Ein Beitrag zur Quellenkunde, I: Westsyrische Originalurkunden, CSCO 307 i 317, Subsidia 35 i 38 Louvain 1970. 